\author{
Perparim Xhaferi \\ University of Sydney \\ rimi.anila@gmail.com
}

\title{
The Post-Ottoman Era: A Fresh Start for Bilateral Relations between Albania and Turkey?
}

\begin{abstract}
This paper will explore bilateral relations between Turkey and Albania during the post-Ottoman period. The aim of the paper is to explore reasons for the revival and establishment of relations since the creation of both nation states at the beginning of the twentieth century. In the $21^{\text {st }}$ century, Turkish foreign policy shifts in the Balkans, along with the rise of the Turkish economy and military capability are in line with Albanian needs politically and economically. More importantly, the Turkey's repeated assurances to protect the Albanian people has been paramount for Albanians who live in the five surrounding states, that is Albania, Kosovo, Macedonia, Montenegro and Serbia.
\end{abstract}

\section{Introduction}

This paper will explore bilateral relations between Turkey and Albania since the creation of the Albanian state in 1912. I examine the economic, security and geopolitical context of Albanian/Turkish interactions since the end of the Cold War. While Albanian foreign policies since the creation of the Albanian state until WWII ${ }^{1}$, communist era ${ }^{2}$, and the post cold war period ${ }^{3}$ have been scrutinised by various

${ }^{1}$ O. Pearson, Albania in the Twentieth Century: A History, Volume I: Albania and King Zog: Independence, Republic and Monarchy, 1908-1939, The Centre for Albanian Studies in Association with I. B. Tauris, London, 2004; Albania in the Twentieth Century: A History, Volume II: Albania in Occupation and War: From Fascism to Communism, 1940-1945, The Centre for Albanian Studies in Association with I. B. Tauris, London, 2005; R. C. Hall, The Balkan Wars 1912-1913: Prelude to the First World War, Routledge, London\&New York, 2000; B. J. Fischer, King Zog and the Struggle for Stability in Albania, Columbia University Press, New York, 1984; R. Falaschi, "Ismail Qemal Bey Vlora and the Making of Albania in 1912", in T. Winnifirth (ed.), Perspectives on Albania: St. Martin's Press, New York, 1992.

2 E. Biberaj, Albania: A Socialist Maverick, Westview Press, Boulder, 1990; E. Biberaj, Albania and China: A Study of an Unequal Alliance, Westview Press, Boulder, 1986; M. I. Bléjer et al., "Albania: from isolation towards reform”, Occasional paper (International Monetary Fund), /98. 1992; W. E. Griffith, Albania and the SinoSoviet Rift, The M.I.T. Press, Cambridge, 1963; H. Hamm, Albania-China's Beachhead in Europe, Frederick A Praeger, New York, 1963; F. S. Larrabee, "Whither Albania?", The World Today, vol. 34, no. 2, 1978; A. Logoreci, The Albanians: Europe's forgotten survivors, Gollancz, London, 1977; D. Tretiak, "The Founding of the SinoAlbanian Entente", The China Quarterly, vol. 10, 1962; M. Vickers, The Albanians: A Modern History, I.B. Taurus, London, [1995] 2001; T. Winnifrith, Perspectives on Albania, St.Martin's Press, Inc., New York, $1992 ; \mathrm{R}$. E. Zickel and W R Iwaskiw (eds.), Albania: A Country Study 2 edn.: Library of congress, Washington, D. C. 1994; O. Pearson, Albania in the Twentieth Century: A History, Volume III: Albania as Dictatorship and Democracy, From Isolation to Kosovo War 1946-1998, The Centre for Albanian Studies in Association with I. B. Tauris, London, 2006.

3 "Shqipëria dhe Këshilli i Partneritetit Euroatlantik (EAPC) [Albania and the Euro-Atlantic Partnership Council]”, Albanian Ministry of Foreign Affairs, 3 March, 2011, "Albania", Oxford Economic Country Briefings, 29 Jul 2009, E Abazi, "Kosovo Independence: An Albanian Perspective”, Seta, Policy Brief, vol. 11, April 2008; Albanian Institute for Intentional Studies, "The European Perspective of Albania: Perceptions and Realities 2010", Tirana, 2010; M Bogdani and J Loughlin, Albania and the European Union: European integration and 
scholars, it is much more difficult to find analyses of the post-Ottoman bilateral relations between Albania and Turkey. Before the recognition of the Republic of Turkey in 1923, there were signs of the beginning of a new era accentuating post-colonial relations between the two countries. ${ }^{4}$ During and after the Cold War, political, economic and defence relations between Albania and Turkey were re-established and strengthened. ${ }^{5}$ While it will be interesting to see whether the new and fragile Albanian democracy needs Turkish political and economic support, there is no doubt that 'small' Albania needs Turkish defence capability in a continuously struggling Balkan region. ${ }^{6}$ Whilst Turkey is one of Albania's strategic partners, it is unclear how strong the relationship is when it comes to defence and security matters. The paper will discuss reasons as to why the Albanian government considers Turkey a stronger ally than other neighbours in the Western Balkans. The strong political relations between Turkey and Albania may improve further after upcoming energy and infrastructure projects such as Trans Adriatic Pipeline (TAP) and the Corridor VIII . The Corridor VIII is one of ten pan-European vital corridors within Central, Eastern and South-eastern Europe established by European conferences of Prague (1991), Crete (1994) and Helsinki (1997). However, it remains to be seen how these developments will affect the EuroAtlantic vision of both countries.

Notwithstanding the fluidity of the relationship between the two countries, I seek to explore some broad questions: What is the Turkish motivation for investing in this relationship, and what is Albania gaining from further strengthening its bilateral relation with Turkey compared to other regional players? Can the strength of Turkish support create a shift in the Albanian focus towards Turkey at a time when the European 'dream' seems far away? Geographically, Albania is situated along the Via Egnatia, which for centuries connected Rome with Constantinople, or what is considered 'East' and 'West'. ' Connections between the Albanian-speaking people and Turks increased during the Ottoman rule of Albanian lands for five centuries. Thus, it will be interesting to examine how these relations developed after Albania's independence in 1912.

\section{From rulers to supporters: The emergence of political relations between Turkey and Albania in the post-Ottoman era}

The first Balkan War broke out on 8 October 1912. A few weeks later, on 28 November 1912, Ismail Qemali declared Albanian independence, which formally ended the Ottoman occupation of the Albanian territories. Exhausted Turkish troops gradually started to retreat from Albanian vilayets, marking the end of the Ottoman era in

\footnotetext{
the prospect of accession, Dajt, Tirana, 2004; I. Kadare, Kombi Shqipetar ne prag te mijevjecarit te trete [The Albanian Nation at the Door of the Third Millenium], Onufri, Tirana, 1998.

4 H. M. Limaj, Midis Ankarasë dhe Tiranës: 199o-20oo. Nga ditari i një atasheu ushtarak [Between Ankara and Tirana: 1990-200o. From the diary of a military attaché], Emal, Tirana, 2012, pp. 29-31.

${ }^{5}$ H. M. Limaj, p. 223.

6 The Balkans have been a historical crossroad of war since the Middle Ages, as the Romans and the Byzantines used the region as a battlefield. The Turkish rule, since the fifteenth century, exacerbated the existing divisions between the Balkan populations. The collapse of the Ottoman Empire at the beginning of the twentieth century caused regional conflict. Two Balkan wars, followed by WWI and WWII led to total economic devastation, and created further division on the Balkan Peninsula. While the Cold War created divisions between communist Albania and other Balkan states, currently, the European Union (EU) is reluctant to accept Western Balkan states as EU members due to their limited economic, political and anti-corruption reforms. On the other hand, Russia's influence in the Balkans is increasing, and thus, is fuelling the Balkan nationalism.

7 M. Bulut and M. Idriz, Turkish Albanian Macedonian Relations: Past, Present and Future, Adam-Actor, Ankara, 2012, p. 9 .
} 
Albania. The retreat of the Turkish troops led to increased anxiety among Albanian leaders, as the founders of the Balkan League ${ }^{8}$ were ready to fill the vacuum left by the withdrawal of the Ottoman troops.

Certainly, Bulgaria, Greece, Montenegro and Serbia showed not the slightest hesitation or moral qualm in planning the partition of Albanian lands. ${ }^{9}$

Faced with the Turkish withdrawal ${ }^{10}$, knowing the aims of the Balkan League and being without support from the Great Powers ${ }^{11}$, Albanians were left with little choice but "to fight for the Turks against their Balkan neighbours". ${ }^{12}$ The Albanian struggle to protect its territorial integrity continued during two Balkan Wars in 1912-13, which "occurred because of the determination of the Balkan states to resolve their issues of national unity in the face of the weakness of the Ottoman Empire and the opposition of the Great Powers". ${ }^{13}$ Not only did the Great Powers fail to enforce ${ }^{14}$ the 1878 Berlin Treaty $^{15}$, in 1914 they found themselves embroiled in WWI. ${ }^{16}$ During WWI Greek, Serbian, Montenegrini, Italian, French, Bulgarian and Austrian troops fought all on Albanian soil. ${ }^{17}$ This was a time when Turkey was dealing with its own internal struggles in trying to replace the Ottoman Caliphate with a modern state in the form of a republic. Mustafa Kemal (Atatürk), who has been described as "the moral and intellectual epitome" ${ }^{18}$ of the Turkish movement, assumed a friendly position towards Albania even before the creation of the Republic of Turkey in $1923 .{ }^{19}$ For example in 1920, Atatürk sent several educated people of Albanian origin back to Albania to help strengthening the Albanian state. ${ }^{20}$ On 1March 1921, addressing the National Assembly

\footnotetext{
${ }^{8}$ Under the auspices of Russia in the spring of 1912 Bulgaria, Serbia and Greece signed an agreement creating 'The Balkan League', which aimed to fight the Ottoman oppressors and free Albanian and Macedonian lands from Turkish domination.

${ }^{9}$ C. and B. Jelavich, "The Establishment of the Balkan National States, 1804-1920”, in P. F. Sugar and D. W. Treadgold (eds.), A History of East Central Europe, VIII: University of Washington Press, Seattle and London, 1977, p. 320.

${ }^{10}$ O. Pearson, Albania in the Twentieth Century: A History, Volume I: Albania and King Zog: Independence, Republic and Monarchy, 1908-1939, p. 2.

11 "Great Powers" is a technical term and refers to a defined set of nation states. At the end of the nineteenth century, Great Powers included Great Britain, France, Italy, Russia, Germany and Austro-Hungary. Before and after the collapse of the Ottoman Empire, at the beginning of the twentieth century, the role of Great Powers was crucial (although problematic) in addressing the Balkan question. Great Powers have had their preferences and interests in the Balkans, creating opinionated and one-sided policies that, in the case of Albania, divided its population into five different nation-states: Albania, Macedonia, Serbia, Montenegro and Kosovo, a situation that continues to generate trouble in the Western Balkans.

${ }^{12}$ P. Morgan, Ismail Kadare: The Writer and the Dictatorship, 1957-1990 Modern Humanities Research Association and Maney Publishing, London, 2009, p. 11.

${ }^{13}$ R. Hall, The Balkan Wars 1912-1913: Prelude to the First World War, p. 21.

${ }^{14}$ An example was the fact that the Treaty of Berlin reversed the recognition of Macedonia within Bulgaria. This was decided in the Treaty of San Stefano in March 1878, returning its territory to the Ottoman Empire. Bulgaria, Greece, Montenegro, and Serbia perceived the Treaty of Berlin as a barrier to their national aspirations". See for instance R. Hall, pp. 3-5.

${ }^{15}$ Great Powers at the time, decided to solve the Balkan question in autumn 1878 a time that their foreign ministers met in Berlin (this meeting is known as 'Treaty of Berlin') with the Prussian Chancellor Otto von Bismarck, who offered to chair as an "honest broker". R. Hall, p. 3.

${ }^{16}$ R. Hall, p. 21.

${ }^{17}$ B. Jelavich, "The Establishment of the Balkan National States, 1804-1920", p. 297.

${ }^{18}$ R. Gingeras, Fall of the Sultanate: the Great War and the End of the Ottoman Empire, 1908-1922, Oxford University Press, New York, 2016, p. 5.

${ }^{19}$ See H. Limaj, Midis Ankarasë dhe Tiranës: 1990-20oo. Nga ditari i një atasheu ushtarak [Between Ankara and Tirana: 1990-2000. From the diary of a military attaché], pp. 29-31.

${ }^{20}$ Atatürk sent several educated people of Albanian origin to Albania to help the establishment of the Albanian state. One of them, colonel Selaudin Shkoza, a man with Prizren heritage, was appointed as the defence minister in the Albanian government in 1920. Shkoza's appointment started to lay foundations for new diplomatic relations between Turkey and Albania. See for instance H. Limaj, p. 31.
} 
of Turkey, Atatürk clarified "sanctuary" links between Turks and "brother" Albanians stating that "we [Turks] are going to help as much as we can" and provide whatever this brother nation-state needs. ${ }^{21}$ He believed in a republican and modern Turkey, and he hoped for Albania to become a free and prosperous country. ${ }^{22}$ At the same time, Atatürk and other Turkish Republican leaders started to repudiate the Ottoman past as a backward and 'non-western' society. This shift accommodated Albania's needs, starting a new chapter of relations between Turkey and Albania. Cultural similarities, commonalities in dealing with oppressors, and the desire to create an independent state led to the formation of new ties between Turkey and Albania after the end of $\mathrm{WWI}^{23}$, a time when Turkey returned to Albania, not as an oppressor, but now as one of main supporters of the inexperienced and poor state of Albania.

\section{Intermittent but cordial political relations between the Republic of Turkey and Albania: 1923-1990}

On 15 December 1923, just over a month after the Declaration of the Republic of Turkey on 29 October 1923, a 'Memorandum of Friendship' between the two states paved the way for another five years of increasing diplomatic relations. This was now a postcolonial agreement between the Republic of Turkey and the Albanian government, led by Ahmet Zogu. Zogu came to power in 1922, establishing an authoritarian regime that filled the political gap left in Albania after WWI. He was a Muslim conservator who was educated at Lycée de Galatasaray in Constantinople and the leader of "conservative landowning beys and tribal heads of bajraktars". ${ }^{24}$ Despite the support of some tribe leaders, his popularity decreased and he lost his legitimacy, fleeing to Yugoslavia after the so-called "June revolution" in $1924 .{ }^{25}$ The reformist and liberal government led by Fan Noli was appointed in June 1924, but only lasted until December 1924, a time that Zogu returned to power, backed by Albanian tribal supporters and the Yugoslav military. ${ }^{26} \mathrm{He}$ declared himself King Zog I in $1928 .{ }^{27}$ Zogu's decision to turn Albania into a monarchy disappointed Atatürk who, despite his sympathy for Albania, terminated diplomatic relations by recalling the Turkish ambassador Tahir Lütfi from Tirana. ${ }^{28}$ In response, Zogu closed the Albanian embassy in Ankara, leaving the fate of many Albanians living in Turkey in the hands of the Italian consulate in Ankara. ${ }^{29}$ The conflict lasted three years, until the second Conference of the Balkans on 20 October 1931. Later, on 14 May 1933, the new Albanian ambassador, Xhevat Leskoviku, met with Atatürk, who in response sent Ruşen Essref as Turkish ambassador to Tirana on 15 April $1934 \cdot{ }^{30}$ Upon his arrival in Albania, Essref met King Zog, who then echoed Atatürk's previous words in describing Turkey as the "big brother" of Albania. ${ }^{31}$ The excellent diplomatic relations between Albania and Turkey were again disrupted in April 1939, by the occupation of Albania

\footnotetext{
${ }^{21}$ H. Limaj, p. 29.

${ }^{22}$ H. Limaj, p. 33.

${ }^{23}$ H. Limaj, pp. 32-33.

${ }^{24}$ P. Morgan, Ismail Kadare: The Writer and the Dictatorship, 1957-1990 p. 12.

${ }^{25}$ M. Vickers, Between Serb and Albanian: A History of Kosovo, Hurst \& Company, London, 1998, pp. 110-111.

${ }^{26}$ O. Pearson, Albania in the Twentieth Century: A History, Volume I: Albania and King Zog: Independence, Republic and Monarchy, 1908-1939, pp. 157-158; Vickers, Between Serb and Albanian: A History of Kosovo, p. 114 .

${ }^{27}$ P. Morgan, Ismail Kadare: The Writer and the Dictatorship, 1957-1990 p. 13.

${ }^{28}$ For the republican Atatürk, the shift to an Albanian monarchy was an enormous step backward.

${ }^{29}$ H. Limaj, Midis Ankarasë dhe Tiranës: 199o-20oo. Nga ditari i një atasheu ushtarak [Between Ankara and Tirana: 1990-200o. From the diary of a military attaché], p. 34.

${ }^{30}$ H. Limaj, p. 34 .

${ }^{31}$ H. Limaj, p. 34.
} 
by fascist Italy. However, when German occupation replaced Italian occupation in 1942, restoring "the formal independence of Albania and, to an extent, respect[ing] the country's sovereignty" the Turkish government re-opened the Turkish Consulate in Tirana. ${ }^{32}$ The withdrawal of Nazi Germany from Albania in the winter of 1944 and the arrival of communism in $1945^{33}$ were momentous events, which severed diplomatic relations between Turkey and Albania completely. On 16 July 1945, the Turkish Ambassador, Muzaffer Kamil Bayur departed Albania. ${ }^{34}$ A decade after this, on 14 December 1955, however, Turkey voted for Albania to become a full member of the United Nations (UN). ${ }^{35}$ Turkey's vote helped Albania to achieve an important goal, and thus was welcomed by Albanian authorities. As a result, the Albanian-Turkish diplomatic relations started to warm up again and culminated in the official reestablishment of diplomatic relations on 13 June $1958 .^{36}$ The Turkish embassy in Tirana re-opened on 27 June of the following year. Following the Turkish coup the next year, diplomatic relations remained formally in place, but without significant interaction. Albania returned Turkey's favour on 18 December 1965 by siding with Turkey against the recognition of Cyprus in an important vote in the UN. Despite the fact that their votes were ultimately unsuccessful, and Cyprus was granted recognition (with the General Assembly resolution 2077 being approved), ${ }^{37}$ this vote boosted relations between the two countries.

During this time, relations between Albania and Russia had also ceased (in 1961), and, due to the difficult relations with its neighbours, Greece and Yugoslavia, Albania came to value Turkey as a strategic ally. ${ }^{38}$ Although Turkey became a NATO member in 1952, and thus, was classified as a western country by the Albanian communist regime, during the Cold War, Albania and Turkey had "few noticeable direct political contacts". ${ }^{39}$ As I have discussed, the Albanian/Turkish relationship has ebbed and flowed over the past century. However, even during the communist period there were no open hostilities between the two countries. The largely political discussion has overlooked the significant cultural exchanges between Turks and Albanians who may not have been aware of what was occurring at a political level. Certainly before the arrival of communism, personal interactions between Turks and Albanians were relatively free. Even during the Cold War, the two countries maintained cultural exchanges in the form of folk dance competitions, as well as academic, sporting, agricultural, tourism and commercial interactions. ${ }^{40}$ While the average Albanian

\footnotetext{
${ }^{32}$ R. Elsie, "1945 Final Report of the German Wehrmacht in Albania”, retrieved from 'Texts and documents of Albanian history', available from http://www.albanianhistory.net/1945_German-Wehrmacht/index.html, last visited on 20 April 2017.

${ }^{33}$ The Albanian Communist Party, Partia Komuniste Shqiptare (PKSH), was founded in 1941, with the participation of Enver Hoxha; assisted by Yugoslav Communist Party delegates. After withdrawal of Nazi Germany from Albania in the winter of 1944, the PKSH came to power, persecuting the political alternative, Balli Kombëtar, as well as intellectual, political and religious figures. See P. Morgan, Ismail Kadare: The Writer and the Dictatorship, 1957-1990 p. 13.

${ }^{34}$ Political relations between the two countries remained static for a decade, until Albanian leaders requested to move diplomatic relations forward.

35 "6o vjet Shqiperi ne OKB [Albania and the United Nations: 6o Years of Partnership]", Albanian Ministry of Foreign Affairs, p. 4.

${ }^{36}$ R. Elsie, Historical Dictionary of Albania, ed. 2, The Scarecrow Press, Inc., Lanham, Toronto, Plymouth, UK, 2010 , p. 455.

37 "Cyprus: New hope after 45 years on the Security Council agenda"; Security Council Report: Special Research Report, 4 September 2008, p. 10.

${ }^{38}$ H. Limaj, Midis Ankarasë dhe Tiranës: 199o-20oo. Nga ditari i një atasheu ushtarak [Between Ankara and Tirana: 1990-200o. From the diary of a military attaché], p. 36.

${ }^{39}$ R. Elsie, Historical Dictionary of Albania, p. 455.

${ }^{40}$ M. Vickers and J. Pettifer, Albania: From Anarchy to a Balkan Identity New York University Press, New York, 1997, p. 221.
} 
citizen faced restricted movement, with tight controls on exit and entry into other countries, these groups represented a minority organised by the Albanian regime. While the government allowed certain groups to travel, for example, to perform at approved contests and competitions, all members of these groups faced similar conditions as the Albanian writers who were strictly scrutinised by the communist regime. ${ }^{41}$ Relations between Albania and Turkey at the grass roots level (i.e. interactions between individuals) faced their own challenges, and it would be interesting to undertake a detailed study of this relatively uncharted area. However, this is beyond the scope of this paper.

In 1968, Ferruh Bozbeyli, the chairman of the Turkish National Assembly, visited Albania in an attempt to discuss ways "to further improve Ankara's ties with the communist leadership of Tirana" ${ }^{42}$, at a time when politically and economically, China was becoming important to Albania. Even during this period, the relations with Turkey were kept very cordial. By the time of the formal break with China in 1978, Albania had become isolated, with an economy on the verge of collapse. Once more, in difficult circumstances for Albania, trade with Turkey resumed. In December 1980, a Turkish delegation visited Tirana. The visit was returned by an Albanian delegation led by Nedin Hoxha, a minister and cousin of Enver Hoxha almost exactly a year later. ${ }^{43}$ In 1988, after a historic meeting of the Albanian foreign minister Reis Malile with the foreign ministers of Yugoslavia, Bulgaria, Greece, Turkey and Romania in Belgrade ${ }^{44}$, Hoxha's successor - the Albanian Chairman of the Presidium of the People's Assembly - Ramiz Alia, welcomed the Turkish foreign minister Mesut Yilmaz to Tirana. ${ }^{45}$ The visit was returned in 1990 by an Albanian delegation. The end of the communist regime in Albania also signified the end of unstable diplomatic relations between Albania and Turkey, to now open a new era of continuous and uninterrupted relations.

\section{The post-communist decade: Establishment of the bilateral political relations as a win-win situation}

In April 1991, Sali Berisha was elected Albanian president, after the Albanian Democratic Party (PD) won the first democratic elections. One of the main challenges for the new fragile Albanian "democracy" was a nearly collapsed economy. Turkey stepped in when Albania's need was at its greatest:

Turkish Foreign Policy in the Balkans was significantly influenced by Turkish President Halil Turgut Ö̉zal who took tremendous advantage of Albania's weak economy and its state of extreme poverty. ${ }^{46}$

\footnotetext{
${ }^{41}$ Peter Morgan mentions that although Albanian writers had better pay and conditions, they were kept under closer scrutiny by the communist regime. Even the work of the well-known Albanian writer, Ismail Kadare, was censured by Hoxha's regime. Therefore it was a constant struggle for Kadare to survive one of the most tyrannic regimes that considered the work of writers and artists as "extremely seriously". See for instance P. Morgan, Ismail Kadare: The Writer and the Dictatorship, 1957-1990, pp. 1-2, 23.

${ }^{42}$ P. Tase, "Albania And Turkey: Two Nations With Common Vision To Strengthen Bilateral Cooperation, 19902000": Retrieved from Foreign Policy News, 25 January 2014, available from http://foreignpolicynews.org/2014/o1/25/albania-turkey-two-nations-common-vision-strengthen-bilateralcooperation-1990-2000/, last visited on16 April 2016.

${ }^{43}$ R. Elsie, Historical Dictionary of Albania, p. 455.

${ }^{44}$ D. Binder, "Rivalry Aside, 6 Balkan Lands Meet and Agree”, The New York Times, 6 March, 1988.

${ }^{45}$ P. Tase, "Albania And Turkey: Two Nations With Common Vision To Strengthen Bilateral Cooperation, 19902000".

${ }^{46}$ P. Tase, "Albania And Turkey: Two Nations With Common Vision To Strengthen Bilateral Cooperation, 19902000".
} 
There are different interpretations of these circumstances. While this implies opportunism, according to Hajro Limaj, the first post-communist Albanian military attaché in Ankara who served for the period from 1990-2000, Turkey acted in generosity. $^{47}$

The facts are that in 1991, through their President Özal, Turkey donated approximately USD14 million to Albania through Eksim Bank ${ }^{48}$ - the first country to offer a postcommunist donation of this scale to Albania. A number of visits from both Turkish and Albanian leaders in years to come brought about an increase in economic, political and defence support to Albania. Money donated to the Albanian government was followed by Turkish investments to restore mosques and religious buildings, ambulances and equipment for hospitals, motor vehicles for the Albanian police forces, along with scholarships given to Albanian 'civilian and military' students to study in Turkey. ${ }^{49}$ In 1992, the Turkish government also granted "USD29 million in the form of food, technology and towards Albania's economic revitalization efforts". ${ }^{50}$

Turkish authorities re-commenced their visits to now 'democratic' Albania on 17-21 November 1991 with the visit of the Turkish General Doğan Güres, Six months later, in June 1992, the Turkish Prime Minister (PM) Süleyman Demirel visited Albania and signed an agreement of bilateral friendship and cooperation with his counterparts. ${ }^{51}$ Demirel was elected as the Turkish PM in 1965, at the time when Albania voted pro Turkey in the UN on the Cyprus issue. ${ }^{52}$ As a constant Albanian sympathiser, he reassured Albanian leaders in 1992 that "Turkey was committed to provide USD50 million in humanitarian and logistical assistance to Albania" ${ }^{53}$

The bilateral relations between Turkey and Albania intensified after the first ministerial meeting held in Ankara on 24 July 1992, further evidenced by the visit of the Turkish President Özal on 18-21 February 1993. Özal, who addressed the Albanian National Assembly, agreed to sign "a fifteen year economic agreement with Albania that would cover a wide area of cooperation from infrastructure projects to military assistance and growth of the tourism industry". ${ }^{54}$ Two months later, in April 1993, the Albanian President, Berisha returned the visit, followed by the Albanian Prime Minister Aleksander Meksi at the end of the same year. During meetings between the two presidents, sensitive issues were discussed. Özal tried to convince Berisha to recognize the new independent state of Macedonia (FYROM), as the only way to improve relations between the two countries, with a goal to make the Balkan region a more peaceful place. Berisha raised concerns regarding tensions with Albania's neighbours, Greece and Serbia, and asked for total economic and defence support from

\footnotetext{
${ }^{47}$ H. Limaj, Midis Ankarasë dhe Tiranës: 199o-20oo. Nga ditari i një atasheu ushtarak [Between Ankara and Tirana: 1990-200o. From the diary of a military attaché], p. 228.

${ }^{48}$ H. Limaj, p. 36.

${ }^{49}$ M. Vickers and J. Pettifer, Albania: From Anarchy to a Balkan Identity p. 221.

${ }^{50}$ Tase, "Albania And Turkey: Two Nations With Common Vision To Strengthen Bilateral Cooperation, 19902000".

${ }^{51}$ H. Limaj, Midis Ankarasë dhe Tiranës: 1990-200o. Nga ditari i një atasheu ushtarak [Between Ankara and Tirana: 1990-2000. From the diary of a military attaché], p. 36.

52 "Cyprus: New hope after 45 years on the Security Council agenda", p. 10.

${ }^{53}$ P. Tase, "Albania And Turkey: Two Nations With Common Vision To Strengthen Bilateral Cooperation, 19902000".

${ }^{54}$ P. Tase, “Albania And Turkey: Two Nations With Common Vision To Strengthen Bilateral Cooperation, 19902000".
} 
Turkey. ${ }^{55}$ The term "total" used by Berisha is clear: at the end of the Cold War, Albanian authorities aimed to fully rely on Turkey.

Albanian authorities were also making moves to signal their closeness to their Turkish counterparts. For example, in December 1992, Albanian delegates decided Albania would become a member of the Organisation of the Islamic Cooperation (OIC), without consulting the Albanian parliament. ${ }^{56}$ This shift triggered a sharp debate that questioned whether Albania's identity was shifting towards Islam and the East. ${ }^{57}$ At this time, Albania secured economic assistance in the form of donations from Turkey, Kuwait and Saudi Arabia, to restore old and build new mosques and Islamic schools. ${ }^{58}$ For Turkey, this was a step in the right direction, bolstering Turkey's support for Muslim Albania, and thus establishing an official presence in the Balkan region.

The collapse of the Albanian government in 1997 (due to failed investment schemes) alongside the worsening situation in Kosovo, brought about another wave of exchange visits between Turkish and Albanian leaders. Thus, on 11 April 1998, the second president of Albania, Rexhep Meidani welcomed the two-day visit of the Turkish President Demirel. This visit was not a simple, friendly meeting between the two presidents. Demirel was escorted by many high ministerial figures, leaders of different Turkish institutions and members of the business community; assisted by a wide coverage from the Turkish media. ${ }^{59}$ The stated aim of this visit was again to help Albanians in difficult times. President Demirel stood before the Albanian parliament and claimed that "65 million Turks are close to the Albanian people", anytime they need help. ${ }^{60}$ Demirel's strong words reaffirmed Turkish support for Albania, while he called for an immediate stop of Serbian atrocities in Kosovo. ${ }^{61}$ After warning the international community that Turkey could not "allow the terrible tragedy of Bosnia [to] happen again", in his speech to the Albanian parliament, president Demirel argued that it was necessary to "immediately halt the bloodshed in Kosovo; restore the fundamental human rights and grant full freedom to Albanians in Kosovo; start a dialogue between all parties immediately and ensure people who were forcefully chased and driven out of Kosovo return to their respective lands." 62

For the Albanian people, the wounds of the period between 1997 and 1999 will need a long time to heal. ${ }^{63}$ While pyramid schemes caused political crises and a quasi civil

\footnotetext{
${ }^{55}$ P. Tase, "Albania And Turkey: Two Nations With Common Vision To Strengthen Bilateral Cooperation, 19902000".

${ }^{56}$ M. Vickers and J. Pettifer, Albania: From Anarchy to a Balkan Identity p. 105.

${ }^{57}$ A. Young, "Religion and society in present-day Albania”, Journal of Contemporary Religion, vol. 14, no. 1, 1999, p. 11.

${ }^{58}$ M. Bogdani and J. Loughlin, Albania and the European Union: The Tumultuous Journey Towards Integration and Accession, I.B. Tauris, Palgrave Macmillan, London, New York, 2007, p. 82.

${ }^{59}$ P. Tase, "Albania And Turkey: Two Nations With Common Vision To Strengthen Bilateral Cooperation, 19902000”.

${ }^{60}$ P. Tase, "Albania And Turkey: Two Nations With Common Vision To Strengthen Bilateral Cooperation, 19902000".

${ }^{61}$ P. Tase, "Albania And Turkey: Two Nations With Common Vision To Strengthen Bilateral Cooperation, 19902000".

${ }^{62}$ P. Tase, “Albania And Turkey: Two Nations With Common Vision To Strengthen Bilateral Cooperation, 19902000".

${ }^{63}$ C. Jarvis, "The Rise and Fall of the Pyramid Schemes in Albania”, in I M Fund (ed.), 1999, p. 30.
} 
war, ${ }^{64}$ that caused around 2000 deaths ${ }^{65}$, Albania's Kosovar brothers were facing a massacre, and an expulsion caused by the military machine of Slobodan Milosevic. Therefore, Demirel's visit was historically very important as it signified support for the Albanian people during the most difficult period since the end of the communist regime. Turkish support was noted by the Albanian President Rexhep Meidani, who emphasized the importance of Albanian-Turkish relations, adding that "Turkey particularly in the decade of the 9os, has extended a hand of hospitality like no other nation to Albania", as did the Albanian Assembly Speaker, Skender Gjinushi, who reaffirmed that the "Albanian Assembly and all political parties, despite their program differences, [...] all want to strengthen bilateral ties with Turkish government". ${ }^{66}$ Demirel's visit was completed with the signing of agreements such as a bilateral agreement on social policy and labour reforms, reviews of the migration policy, employment monitoring and analysis, media ${ }^{67}$ and research on the impact of social policies in Albanian communities. These agreements ensured that at the close of the twentieth century, relations between Turkey and Albania finished on a high, and suggested a promising start to the twenty-first century.

At this time Turkey also played an important role in NATO missions in Kosovo in 1999. NATO jets not only used the proximity of Turkish bases, but Turkey had direct involvement: providing 18 fighter jets to conduct surveillance operations over Serbian airspace. On the 28-29 February 2000, Turkish Prime Minister Bülent Ecevit paid an official visit to Albania. ${ }^{68}$ In his meeting with the Albanian PM, Ilir Meta, Ecevit denied the brutal treatment of Turkish minorities by Serbian forces in Kosovo and emphasized Turkish support for Albania.

\section{Continuity of the Turkish-Albanian political relations in the twenty-first century}

The twenty-first century opened with two major events for Albanians: The Kosovar parliament declaring independence from Serbia in 2008, and Albania becoming a NATO member in 2009. In both cases, Turkey was in the front line, recognising the Republic of Kosovo from day one and lobbying for Albania to become a NATO member. Turkish support for Albania is not welcomed by Albania's neighbours Serbia and Greece. Greek foreign policy with regards to Kosovo is in line with Serbian authorities beliefs, which consider Kosovo part of Serbia cut off by NATO in 1999. The situation is different when it comes to the NATO issue. Greece is a NATO member, and thus, needs to share values with Albania, whereas Serbia counts on Russia's political and military support. Therefore, it seems that what unites both Serbia and Greece against Albania

\footnotetext{
${ }^{64}$ In 1997, the Albanian government lost control and some areas of Albania. In the absence of government authority, armed gangs took control of entire areas. For example the city of Vlorë was controlled by two gangs that were related to the Albanian main political opponents: Gaxhai's gang that was supported by Democratic Party and Zani's gang, that served the Socialist Party. See for instance 'Vlora 20 vjet me parë: Si e e priti Zani Caushi me armë Prodin [Vlora 20 years ago: How armed Zani Caushi received Prodi]'. Panorama on line, 26 January 2017, retrieved from http://www.panorama.com.al/fotolajm-vlora-20-vjet-me-pare-si-e-priti-zani-caushi-me-arme-prodin/, last visited on 23 February 2017.

${ }^{65}$ C. Jarvis, "The Rise and Fall of the Pyramid Schemes in Albania”, p. 31.

${ }^{66}$ P. Tase, "Albania And Turkey: Two Nations With Common Vision To Strengthen Bilateral Cooperation, 19902000".

${ }^{67}$ The Albanian Telegraphic Agency signed a memorandum of cooperation with the Anatolu Ajans (AA) Turkish news agency. In addition, the Albanian national TV channel signed an agreement with the Turkish TV channel ARD, which included a series of programs, training and logistics that Albania would receive from the ARD.

${ }^{68}$ H. Limaj, Midis Ankarasë dhe Tiranës: 1990-2000. Nga ditari i një atasheu ushtarak [Between Ankara and Tirana: 1990-2000. From the diary of a military attaché], p. 36.
} 
is the ghost of the 'Greater Albania' ${ }^{69}$ As a result, for Albanian authorities, Turkey's foreign policy is more closely aligned with their needs. Visits from politicians and higher officials from both governments intensified the tradition of maintaining periodic meetings. The Albanian President, Alfred Moisiu, visited Turkey in May 2003, and a week later, Turkish PM Erdoğan paid a courtesy visit to Tirana. This was the second time Erdoğan visited Tirana as a PM, and he was to return again in 2013 and 2015 as President. The next Albanian President, Bamir Topi, and the Albanian PM Sali Berisha visited Turkey in April 2012. In October of the same year, the Albanian foreign minister, Edmond Panariti visited Turkey and held talks with the then Turkish foreign minister Ahmet Davutoğlu. Turkish foreign minister Davutoğlu, visited Albania on 45 October 2013. During his visit, Davutoğlu aimed to establish high-level strategic cooperation mechanisms, and create sustainable political, economic and trade relations between the two countries. Since his election as Prime Minister, on 23 June 2013, Edi Rama highlighted the need for Albania's "strategic relations with Turkey", which were to be given an immediate and "special priority" ${ }^{70}$ The Albanian Defence Minister, Mimi Kodheli and the foreign minister Ditmir Bushati visited Turkey on 1819 April 2014. While Kodheli signed a secret treaty ${ }^{71}$ with her Turkish counterpart, Bushati's first visit as the Albanian foreign minister to Turkey aimed to further extend bilateral cooperation, which is enjoying a new momentum after the official visit of Davutoğlu to Albania in 2013. According to Davutoğlu, Albania and Turkey will endeavour to work together in order to achieve common goals as the 'High Level Cooperation Council' between Turkey and Albania is established. ${ }^{72}$

Albania and Turkey have common goals indeed. Under the NATO flag, they worked closely in Peace Keeping operations in Afghanistan, Bosnia-Herzegovina, and other hot spots in the world, participated in the Southeast European Cooperation Process (SEECP), and are both members of the OIC. During the post-Cold War period, intermittent but continuous visits between Albanian and Turkish leaders have boosted the bilateral relationship between the two countries. For Turkey, the 'little sister' Albania is deserving of assistance, and for Albania, economic and security matters are crucial. More importantly, the Albanian position in the region will be stronger through the support of the undisputable 'big brother' - USA, while Turkey can be a closer regional partner for Albania.

\footnotetext{
${ }^{69}$ The paranoia of a 'Greater Albania' seems to have not come to an end. While for First Deputy Prime Minister and Minister of Foreign Affairs Ivica Dačić, the danger of Albanian expansionism seems to be everywhere - "in the drone flying over the now infamous Albania-Serbia football match; at Albanian Prime Minister Edi Rama's residence, where a light display projected the map of Greater Albania for New Year's; and in the West's silence"; the Greek defence minister, on the other hand, condemned and punished seven Greek soldiers of the Albanian origin who had formed the Albanian double eagle symbol with their hands. See SBS Australia, 'Two years of SYRIZA ruling Greece - The Albanian eagle in the Greek army!', 26 Jan 2017, retrieved from http://www.sbs.com.au/yourlanguage/greek/en/content/two-years-syriza-ruling-greece-albanian-eagle-greekarmy, last visited on 12 February 2017; S. Kushi and O. Kushi, "The Paranoia over "Greater Albania" Returns", New Eastern Europe, 21 January 2015.

$7^{\circ}$ P. Tase, "Turkey and Albania establish a dynamic agenda of bilateral relations": Foreign Policy News, 2 May 2014.

${ }^{71}$ The annual military help from Turkey ended up as a secret treaty signed by the defence ministers of the two countries in 2014. It consisted of USD 1.137.500 offered by Turkey to the Albanian defence forces in order to modernise its military equipment, modernise the military airport of Kuçovë and facilitate training of the Albanian troops in Turkey. ${ }^{71}$ This agreement contains two conditions: 90 percent of this amount will be paid by Turkey and only 10 percent will be paid by Albania; it also bars Albania from selling or using the Turkish military technology elsewhere without Turkey's permission. See H. Mesi, "Turqia, marrëveshje të fshehtë me Shqipërinë për modernizimin e FA-ve [Secret agreement between Turkey and Albania to modernise military forces]", Gazeta Shqip, 17 Shkurt 2014.

${ }^{2}$ P. Tase, "Turkey and Albania establish a dynamic agenda of bilateral relations".
} 
However, the motivations for Albanian-Turkish political relations are still contested. One might easily raise some questions: Has Turkey's motivation been solely humanitarian with no hidden agenda? Is Albania being forced to rely on Turkey in tough times? What are the advantages of the Turkish "soft power" intervention?

According to the Albanian foreign affairs ministry Albania has signed 74 bilateral agreements with Turkey between 1992 and 2013; more than with any other country, except Italy and Germany. ${ }^{73}$ It is of note that 29 of these agreements (or 39 per cent) concern military and defence matters. The majority of these agreements - 71 - were signed in the twenty-first century, indicating a sharp increase in defence and military agreements, but also an intensification of Turkish diplomatic relations with Albania.

\section{Turkey's twenty-first century 'zero problems with neighbours' foreign policy}

Despite its claims of being a 'secular' and 'democratic' state, Turkey has been described as a "non-Western country" that is only beginning to attempt "to organise its society on Western lines". ${ }^{74}$ Taspinar writes, "Turkey is deeply polarized over its Muslim, secular, and national identities". ${ }^{75}$ Turkish society has been divided into two main political factions for a long time: those who are sympathetic to secular republicans known as "Kemalists", and others who side with the "Islamic neo-Ottomanists". ${ }^{76}$ However, with regards to Turkish foreign policy in the Balkans, Turkey's political elite has always paid special attention to Albania. Historically, Albanian leaders have welcomed this, as they perceive Turkey to be a political, economic, and security guarantor. In addition, there is a significant population of Turks with Albanian heritage living in Turkey. The former Albanian Ambassador in Turkey, Genci Muçaj estimates that five million Turkish citizens of Albanian descent have significant links to their cultural heritage. ${ }^{77}$ Although they are not a big source of remittances for Albania, these people create a cultural and economic bridge between the two countries, and help to achieve what Muçaj describes as three Albanian diplomatic priorities in Turkey, namely "bilateral relations, economic and cultural diplomacy". ${ }^{78}$

Ömer Taspinar claims that Turkey's foreign policy in the twenty-first century has a focus on the Middle East, while being trapped between 'secular Kemalists' and 'Islamic neo-Ottomanists' ${ }^{79}$ Hence, according to Taspinar, Ankara will be careful to "balance its neo-Ottoman and Kemalist instincts". ${ }^{80}$ Unlike Taspinar, Žarko Petrović and Dušan Reljić believe that Turkey is shifting its foreign policy focus to the Western Balkans instead as "relations between Turkey and the Western Balkans have never been more

\footnotetext{
${ }^{73}$ While the majority of bilateral agreements between Albania and Germany and Albania-EU are focused on finance and technical matters, in 1992 and 1997 Albania signed two agreements to collaborate on military and defence matters with both Italy and Greece. See "Marrëveshjet dypalëshe me të gjitha vendet [Bilateral relations with all countries]", Ministry of Foreign Affairs of the Republic of Albania.

${ }^{74}$ A. Mango, The Turks Today, John Murray, Great Britain, 2004, p. 253.

75 Ö. Taspinar, “Turkey's Middle East Policies: Between Neo-Ottomanism and Kemalism”, Carnegie Endowment for International Peace 10 (September 2008), p. 2.

${ }^{76}$ Ö. Taspinar, "Turkey's Middle East Policies: Between Neo-Ottomanism and Kemalism”, p. 28.

77 “Ambasadori i Shqipërisë në Turqi: Feja e shqiptarit është shqiptaria, në Turqi janë pesë milionë shqiptarë [The Albanian Ambassador in Turkey: The Albanian religion is Albanianism, in Turkey live five million Albanians]": Telegrafi.com, 2 August 2015.

78 “Ambasadori i Shqipërisë në Turqi: Feja e shqiptarit është shqiptaria, në Turqi janë pesë milionë shqiptarë [The Albanian Ambassador in Turkey: The Albanian religion is Albanianism, in Turkey live five million Albanians]".,

${ }^{79}$ Ö. Taspinar, “Turkey's Middle East Policies: Between Neo-Ottomanism and Kemalism”, p. 28.

${ }^{80}$ Ö. Taspinar, p. 28.
} 
intensive since the foundation of the Turkish republic" ${ }^{81}$ Davutoğlu's speech on 16 October 2009 at the "Ottoman legacy and Balkan Muslim Communities" conference in Sarajevo " is described as a shift in Turkish foreign policy in the Balkans. ${ }^{82}$ By 2009 , Turkish political initiatives in the Western Balkans went far beyond a "bandwagon" approach with the US policies in the Balkans. ${ }^{83}$ For Petrović and Reljić, Turkey "has leverage and increasingly capacities in the Western Balkans" which must be accepted and recognized by the EU. ${ }^{84}$ However, according to these authors, Turkey - a country with a "partly Islamic identity", is "arguably growing stronger". ${ }^{85}$ For others such as Edward Erickson, there is no doubt that Turkey is working to become the main power of the region, and it is merely a question of when it will happen. ${ }^{86}$

Turkey uses its influence in the Balkans as an example of its geopolitical importance and Ankara wants to demonstrate that a permanent peace in the Balkans is unattainable without Turkey's help ${ }^{87}$

In his speech at the end of the Turkish elections in July 2011, Erdoğan claimed that AKP's victory aimed to serve not only the Turkish people, but that "The Middle East, the Caucasus, and the Balkans have won as much as Turkey". ${ }^{88}$ A year before, Turkey's former foreign minister Davutoğlu revealed the country's twenty-first century foreign policy. Its slogan "zero problems with neighbours" encapsulated the policy, known as the "Davutoğlu doctrine". ${ }^{89}$ In this foreign policy Davutoğlu states that:

Turkey has multiple goals over the next decade: First, it aims to achieve all EU membership conditions and become an influential EU member state by 2023 . Second, it will continue to strive for regional integration, in the form of security and economic cooperation. Third, it will seek to play an influential role in regional conflict resolution. Fourth, it will vigorously participate in all global arenas. Fifth, it will play a determining role in international organizations and become one of the top 10 largest economies in the world. ${ }^{90}$

This quote is strong evidence of Turkey's desire to step forward onto the global stage. Davutoğlu's tone and the strength of his language is an indication that he wants Turkey to become a 'key' EU member, 'play an influential role in regional conflict resolution' and 'vigorously participate' in global arenas. While it is not clear whether Turkey's 'influential' role is reliant on Turkey becoming an EU member, the second and third goals of Turkish foreign policy are a direct involvement with regards to security, economic cooperation and conflict resolution in the region. However, "Turkey's region" needs to be clearly identified. Is it the old Ottoman Empire territory in the Middle East, Asia and the Balkans, or simply a geographical area that comprises

\footnotetext{
${ }^{81}$ Ž. Petrović and D. Reljić, “Turkish Interests and Involvement in the Western Balkans: A Score-Card”, Insight Turkey, vol. 13, no. 3, 2011, p. 169.

${ }^{82}$ Ž. Petrović and D. Reljić, p. 162.

${ }^{83}$ Ž. Petrović and D. Reljić, p. 160.

${ }^{84}$ Ž. Petrović and D. Reljić, 159.

${ }^{85}$ Ž. Petrović and D. Reljić, p. 160.

${ }^{86}$ E. J. Erickson, "Turkey as regional hegemon-2014: strategic implications for the United States", Turkish Studies, vol. 5, no. 3, 2004.

${ }^{87}$ E. Türbedar, “Turkey's New Activism in the Western Balkans: Ambitions and Obstacles”, Insight Turkey, vol. 13, no. 3, 2011, p. 154.

88 "Erdogan's speech to the Turkish electorate June 2011, in Cornell, SE 'Changes in Turkey: What Drives Turkish Foreign Policy?", Hürriyet; Istanbul, June 13, 2011, p. 13.

${ }^{89}$ A. Davutoğlu, “Turkey’s Zero-Problems Foreign Policy”, Foreign Policy, 20 May 2010.

90 A. Davutoğlu.
} 
modern nation-states that surround the Republic of Turkey? Nevertheless, Turkey's role in 'region integration' with regards to 'security and economic cooperation' is exactly what Albania wants Turkey to do: be Albania's economic and military guarantor in the region. According to Davutoğlu, "Turkey's actions are motivated by a great sense of responsibility, entrusted to it by its rich historical and geographic heritage, and by a profound consciousness of the importance of global stability and peace". "While the historical links between Albania and Turkey do exist, one can question their 'geographic heritage'.

It has been proposed, and seems historically accurate that in 1378, the Ottoman Turks were invited to enter what constitutes today's Albania by the feudal lord of Durrës, Karlo Topia, in order to help him in his conflict with the Balsha family. ${ }^{92}$ The Ottomans not only crushed the Balshas at the battle of Savra (near Lushnjë) on 18 September 1385, but also conquered other surrounding Albanian principates, making their feudal lords vassals of The Sublime Porte ${ }^{93}$. From this first involvement in the region, the Ottomans conquered and ruled the Albanian speaking lands and the entire Balkan Peninsula for centuries. Although the situation in the twenty-first century is different, the re-emergence of Turkish interest in Albania is again challenging the Balkans. While the aim of both Turkish and Albanian governments is closer relations, it is unclear whether the Albanian people support this. There have been indications that some Albanian citizens do not desire increased Turkish presence in Albania. For example, Albanians vandalised Hasan Pasha's memorial at the city of Shkodër on 16 July $2016^{94}$ and removed the Turkish flag, after Turkish commentator Talha Uğurluel called Skanderbeg a "bandit" who came down from the mountains attacking women and children, in the same way that terrorist Kurds attack Turkey today. ${ }^{95}$ This was followed by the removal of all Turkish flags placed at Prishtinë streets during Independence Day celebrations of Kosovo on 17 February 2017. ${ }^{96}$ It is unclear whether these are isolated acts of a small number of people, or part of a growing popular sentiment.

In the last few decades, Turkish foreign policy has shown variations and has been what Cornell describes as a "less predictable force than it used to be and one whose policies will occasionally clash with those of the West". ${ }^{97}$ In reality, Turkey and the West "cooperate when their interests align rather than as a result of shared values". ${ }^{8}$ The absence of common values between the West and Turkey makes Turkish foreign policy unpredictable and unique.

The post-Cold War era has been also a period of reformation in the Turkish armed forces. This brought about a modern and capable Turkish army, operating within NATO since 1990 in missions in places such as Bosnia, Somalia, Kosovo and

\footnotetext{
${ }^{91}$ A. Davutoğlu.

${ }^{92}$ T. Winnifrith, Perspectives on Albania, p. 77.

${ }^{93}$ The Sublime Porte, also known as the Ottoman Porte or High Porte, is often used as a synonym of the central government of the Ottoman Empire.

94 "Shkodër, dëmtohet memoriali i Riza Pashës. Hiqet flamuri turk [Shkodër, damage of the Riza Pasha memorial. Turkish flag disapeared]”, Top Channel, 7 July 2016.

95 "Historiani turk fyen Skënderbeun, reagime të forta kundër tij [Turkish Historian offends Skanderbeg, strong reactions against him]", Top Channel, 5 July 2016.

96 "Hiqet flamuri turk në Prizren. Reagon Ministria e Jashtme e Kosovës [Turkish flag removed in Prizren. Reacts Kosovar foreign Affairs Ministry]”, in K Jone (ed.), 17 February, 2017.

${ }^{97}$ S. E. Cornell, "Changes in Turkey: What Drives Turkish Foreign Policy?", Middle East Quarterly Winter 2012, published in Hürriyet (Istanbul), 13 June 2011, p. 24.

${ }_{98}$ S. E. Cornell, p. 23.
} 
Afghanistan. ${ }^{99}$ Erickson believes that factors such as 'terrorism' and 'Islamic fundamentalism' are both 'potential triggers' for the rise of Turkish power. ${ }^{100}$ The latest agreement between Putin and Erdoğan to deliver Russian gas through Turkish pipelines to southern Europe ${ }^{101}$ and to join forces in the war against terrorism can be seen as further evidence of Cornell's thesis that Turkish foreign policy is becoming increasingly unpredictable. It has also created instability in the Balkan region. While Putin is getting closer to Erdoğan, the anxiety of Kosovar Albanians is increasing, as they see the US and Turkey as their protectors against Serbian plans to regain Kosovo. There is also great fear among Albanian Kosovars regarding the relationship between the new American President, Donald Trump and Putin. They believe that Putin will return Kosovo to Serbia. ${ }^{102}$

\section{The rise of the Turkish-Albanian post-Cold War economic relations}

The economic situation in Turkey improved from the mid-1980s as a result of the introduction of acceleration policies by Prime Minister, then President, Turgut Özal. As a result, agricultural and industrial production rose by 38 to 41 per cent respectively between 1980 and 1998. ${ }^{103}$ By 2001, however, the Turkish economy had gone into recession ${ }^{104}$. Nevertheless, according to Prime Minister, Ahmet Davutoğlu, Turkey's economic future was brilliant and his government's ambitious plan was to become "one of the top 10 largest economies in the world" ${ }^{105}$ by 2023. Although the Turkish economy has enjoyed growth over the past decades, in 2016, it showed signs of declining 'from $17^{\text {th }}$ to $19^{\text {th }}$ place in the rankings of the biggest economies' in the world. ${ }^{106}$ In the first month of 2016, Turkish exports to Western partners, Germany, Great Britain, Italy and the USA, declined by 14.4 per cent, whereas exports to Saudi Arabia and Egypt rose by 30.5 and 15.1 per cent respectively. ${ }^{107}$ The Turkish government is working hard to finalise free trade agreements with Iran, and improve its relations with Israel, which will bolster Turkey's ambition to become a regional leader. Shifts by the Turkish government from the West to its 'comfort zone' - the Middle East are not unknown; rather they show fluctuations in Turkey's foreign policy and its international reputation, which according to the former Canadian defence attaché to Turkey, Chris Kilford, is 'in free-fall'. ${ }^{108}$ In the context of Turkey's ambitious plans for economic growth as outlined earlier it is possible that the strengthening of

\footnotetext{
${ }^{99}$ E. J. Erickson, “Turkey as regional hegemon-2014: strategic implications for the United States”, vol. 5, p. 32.

${ }^{100}$ E. J. Erickson, p. 42.

101 "Putin dhe Erdogan armiq të betuar? Marrëveshja e madhe e bashkëpunimit [Putin and Erdogan sworn enemies? The big friendship agreement]”, Panorama online, 8 February 2017.

${ }^{102}$ It seems that the election of Donald Trump as the President of the United States has encouraged Serbia to action on three different fronts at the beginning of 2017: former Kosovar Prime Minister Ramush Haradinaj was arrested in France under a Serbian Interpol order for war crimes while being dismissed twice by the Hague's court; a train with posters "Kosovo is Serbia" written in 21 different languages attempted to enter Kosovo and was stopped at the last minute, and the illegal wall built by Serbians in Mitrovica, which was pulled down after peaceful negotiations between Serbian and Albanian authorities in February 2017. D Welle, "Kosovo fears for US ties under Trump", 2017.

${ }^{103}$ E. J. Erickson, “Turkey as regional hegemon-2014: strategic implications for the United States", vol. 5, p. 28.

${ }^{104}$ E. J. Erickson, p. 36.

${ }^{105}$ Davutoğlu, “Turkey's Zero-Problems Foreign Policy”.

${ }^{106}$ M. Aksoy, "Turkish economy declines from 17th to 19th place in ranking of biggest economies": Today's Zaman, O1 January 2015.

107 “Turkey's exports drop 14.4 pct in first month of 2016”: Hürriyet Daily News, 1 February 2016.

${ }^{108}$ C. Kilford, “Turkey's international reputation in free-fall”: Today's Zaman, 1 February 2016.
} 
economic ties with Saudi Arabia and Egypt will cause Turkey to align itself more with the Middle East than the West.

Regardless of Turkish foreign policy fluctuations, Turkey is a much bigger and richer country than Albania and, therefore, an important strategic partner for Albania. Turkey's population of approximately 80 million is 27 times bigger than the number of Albanians who still live in Albania; but most importantly, the Turkish Gross Domestic Product (GDP) is approaching 800 billion US dollars, which is nearly 57 times bigger that the Albanian GDP. These figures are a clear indication that Turkey has significantly more leverage in the bilateral relations between the two countries.

Albania is central to the new Turkish engagement policy in the Balkans. According to Turkey's commercial attaché for Albania, Muharrem Can, in 2013, Turkish businesses invested "1.5 billion [US] dollars, or about 10.5\% of the Albanian GDP", whereas Albania's Turkish Ambassador Hidayet Bayraktar stated recently that the Turkish foreign direct investments (FDI) in Albania increased to 2 billion Euros. ${ }^{109}$ The Turkish foreign ministry website states that "Turkey is the second major trade partner of Albania" with a value of investments "over 1 billion Euros". ${ }^{110}$ Other literature points out that in 2014, "Turkish investments in Albania have increased by US $\$ 2$ billion and the bilateral trade volume has reached more than US $\$ 1$ billion, from US $\$ 400$ million, only five years ago". ${ }^{111}$ The economic connections between two countries are rapidly strengthening.

The Turkish government is facilitating economic and cultural ties with Albania through its Cooperation and Coordination Agency (TIKA) and the Yunus Emre Turkish Cultural Center in Albania. Following requests from the Albanian government, TIKA is investing to restore "mosques, bazars and historical houses" in Albania. ${ }^{12}$ At the end of July 2012, Turkey's contribution to the Albanian economy passed USD 120 million. ${ }^{113}$ As has been described, a significant proportion of that contribution has been dedicated to cultural restoration.

Leading Turkish companies have invested and operate in crucial sectors of the Albanian economy. ${ }^{114}$ Large Turkish companies such as ENKA, Gintaş, Armada, Metal Yapı, Aldemir, and Servomatik are involved in construction and the building industry in Albania. Others such as Çalık Holding, Türk Telekom, Makro-Tel and Hes Kablo are involved in telecommunications. The only Albanian national telephone company, Albtelecom, along with Eagle Mobile, are owned by BKT, a Turkish company. Similarly, the Turkish Çallk Group owns Albania's second biggest bank - Banka Kombëtare Tregtare [The National-Commercial Bank]. ${ }^{115}$ Şekerbank-BKT is present in banking and telecommunications. Kürüm has invested in the iron and steel industry, managing a steel factory, the only functional part of the previous backbone of the Albanian mineral industry - the Elbasan metallurgic factory.

\footnotetext{
${ }^{109}$ G. Mlloja, "Relations between Turkey and Albania are at an excellent level”: Albanian Daily News, an interview with the Turkish Ambassador to Albania, Hidayet Bayraktar, 29 October 2015.

110 "Relations between Turkey and Albania": Republic of Turkey: Ministry of foreign affairs

${ }^{111}$ P. Tase, "Turkey and Albania establish a dynamic agenda of bilateral relations".

112 G. Mlloja, "Relations between Turkey and Albania are at an excellent level".

${ }^{113}$ H. Limaj, Midis Ankarasë dhe Tiranës: 1990-20oo. Nga ditari i një atasheu ushtarak [Between Ankara and Tirana: 1990-200o. From the diary of a military attaché], p. 40.

${ }^{114}$ G. Mlloja.

115 “'The Banker" reaffirms BKT as 'the best bank in Albania' for 2013”: Çalık Holding.
} 
Turkish investments are also very present in other sectors of the Albanian economy such as health with Universal Hospital Group; mining with Ber-Oner and Dedeman; manufacturing and consumer goods retail with Yilmaz Cable, Merinos, Everest, Pino and RM Kocak. Education is another sector influenced by Turkish organisations: Turkish Gülistan and Istanbul Foundations have invested heavily in all stages of education from primary schools to tertiary education. Turkish companies manage four medium hydropower plants, the largest port of Albania - Durrës goods terminal, and important parts of the Albanian infrastructure, such as the construction of the NorthSouth freeway Rruga e Kombit, which connects Albania with Kosovo. To support these companies, 474 Turkish citizens reside in Albania (more than Italian and Greek citizens), operating under work permits. ${ }^{116}$

While the Albanian media has described Turkish economic involvement in Albania as "the second invasion" 117 of Albania, Muharrem Can thinks that the Turkish government does not seek to economically dominate the region. According to Can, the increase in import-export with Albania is a result of the Turkish economy growing rapidly in the region. ${ }^{118}$ Can's diplomatic statement does not negate the increase of Turkish soft power over Albania. In reality, the Turkish Ambassador, Bayraktar, is "not satisfied with these [economic] figures, when comparing the excellent level of our [Turkish and Albanian] political relations". ${ }^{119}$ Strengthening bilateral economic ties in the future will help the weak Albanian economy, whilst bringing Turkey closer to the western Balkans.

\section{Turkey: a NATO teammate and Albania's guarantor}

The defence sector has been another area of strong cooperation between Turkey and Albania. Under the NATO mandate, Albania had a unit of soldiers operating in Afghanistan, "serving within the Turkish command deployed in Kabul". ${ }^{20}$ Although Albania became a NATO member in 2009, since the end of the Cold War, Albania has depended heavily on Turkish "assistance in training and supply of cutting edge defence technology, as well as the reconstruction of Albania's military bases and their maintenance". ${ }^{121}$ According to Limaj, a new era of military partnership between the two countries started on 19 November 1992, with the signing of a partnership agreement to educate and train the Albanian forces. ${ }^{122}$ For the then Turkish Defence Minister, Nevzat Ayaz, the "agreement focused on broadening bilateral cooperation in the areas of military education and technology." ${ }^{123}$ As part of this agreement, Turkish military personnel of "infantry, land, naval and Air Force bases have trained Albanian Armed Forces", providing "technological equipment" and helping to "rebuild its military infrastructure". ${ }^{124}$ There have been an increasing number of high-level government visits between Albania and Turkey since then. For example, between 19 January and 20 November 1992, the Albanian Army General Kristaq Karoli, Defence

\footnotetext{
116 "Turqit 'pushtimi i dytë' i Shqipërisë nga biznesi [Turks 'the second invasion' of Albania from the business]": Mapo, 25 Shkurt 2013.

117 “Turqit 'pushtimi i dytë' i Shqipërisë nga biznesi [Turks 'the second invasion' of Albania from the business]”.

118 "Turqit 'pushtimi i dytë' i Shqipërisë nga biznesi [Turks 'the second invasion' of Albania from the business]".

${ }^{119}$ G. Mlloja, "Relations between Turkey and Albania are at an excellent level".

${ }^{120}$ P. Tase, "Turkey and Albania establish a dynamic agenda of bilateral relations".

${ }^{121}$ P. Tase, "Turkey and Albania establish a dynamic agenda of bilateral relations".

${ }^{122}$ H. Limaj, Midis Ankarasë dhe Tiranës: 1990-20oo. Nga ditari i një atasheu ushtarak [Between Ankara and Tirana: 1990-200o. From the diary of a military attaché], p. 38.

${ }^{123}$ H. Limaj, p. 38.

${ }^{124}$ P. Tase, "Turkey and Albania establish a dynamic agenda of bilateral relations".
} 
Minister Safet Zhulali and General Ilia Vasho visited Turkey. The Turkish General Doğan Güres, and the Defence minister Nevzat Ayaz returned their visit in the same year.

During his visit to Albania, the Turkish defence minister, Ayaz stated that it is Turkey's 'obligation' to help its 'sister', Albania. The Albanian defence minister Safet Zhulali visited Turkish military basis and factories; sharing sensitive information at a time no other defence minister from a country that was not a NATO member had done before. ${ }^{125}$ A month later, after the Albanian delegation returned from Turkey on 28 August 1992, "the Turkish Gearing Class destroyer, TCG Mareşal Fevzi Çakmak," visited the Albanian port of Durrës. ${ }^{126}$ Both of these episodes can be interpreted as an indication of the high level of trust between the two countries, but they also demonstrate the need for both Albania and Turkey to show Turkey's power. The collaboration between Albania and Turkey in economic and defence matters seems not only to bolster political relations between the two countries, but also to reassure the Albanian government. More recent evidence of the strong ties between the two countries includes high Albanian military officials proudly welcoming the visit of the Turkish submarine "TCG Sakarya" to Durrës on 10 November 2014. ${ }^{127}$

According to 'official statistics', Turkey has spent more than any other country in training all levels of the Albanian military forces thus far. ${ }^{128}$ Turkey has equipped the Albanian Guard of the Republic, trained the Albanian special troops, reconstructed the Albanian military base at Pashaliman, the Marine Academy of Vlorë and the Air force Academy of Kuçovë; it has also modernised the munitions factories at Poliçan and Gramsh. Between 1992 and 2000, more than 1000 Albanian students and military officials were educated at the Turkish academies, and Turkish military officials trained 3491 Albanian troops in Albania. ${ }^{129}$ In the last two decades, "many Albanian military students [graduated or are] studying in the Turkish War Academies", and "from 1998 onwards, over 100 Albanian students graduated from the National Police Academy". ${ }^{130}$ It has been argued that as a result of this involvement, Turkey has an intimate and detailed knowledge of Albanian security matters.

While these indicators show Turkey as a trustworthy strategic partner for the Albanian government, when one takes into account the history of relations between the two countries, it is not so clear as to why Albania trusts Turkey on security matters. At the beginning of the twentieth century, Turkey was considered by some Albanian leaders as the only hope to protect Albania from being partitioned by its neighbours. On the other hand, as Peter Sugar mentions, "the Ottoman political legacy must be considered the greatest problem faced by peoples who, once again, had become masters of their own destiny". ${ }^{131}$ At present, Albanian policy makers need the military muscle of Turkey. According to Limaj, the latest example was the decision of Turkey to protect

\footnotetext{
${ }^{125}$ P. Tase, "Albania And Turkey: Two Nations With Common Vision To Strengthen Bilateral Cooperation, 19902000".

${ }^{126}$ P. Tase, "Albania And Turkey: Two Nations With Common Vision To Strengthen Bilateral Cooperation, 19902000".

127 'Turkish submarine “TCG Sakarya” visits the port of Durrës': Albanian Armed Forces, 10 November 2014.

${ }^{128}$ H. Limaj, Midis Ankarasë dhe Tiranës: 1990-20oo. Nga ditari i një atasheu ushtarak [Between Ankara and Tirana: 1990-200o. From the diary of a military attaché], p. 39.

${ }^{129}$ H. Limaj, p. 41.

${ }^{130}$ G. Mlloja, "Relations between Turkey and Albania are at an excellent level".

${ }^{131}$ P. F. Sugar, Southeastern Europe under Ottoman Rule, 1354-1804, University of Washington Press, Seattle, 1977 , p. 288.
} 
the territorial integrity of Albania during the political turmoil in $1997^{132}$. During these revolts the state lost control of some parts of Albania, and according to Limaj, there were international plans to divide Albania. ${ }^{133}$ Following the advice by the Turkish General Karadaj, on 29 March 1997, the Turkish PM Tansu Çiller stated:

Turkey will protect the territorial integrity of Albania and cannot stay passive in the face of events that threaten to divide Albania. 134

For Bayraktar, "Turkey has a lot to contribute to the future of the Balkans together with the EU", however, a small group of authors and historians "are evaluating and distorting the common history" and "triggering negative feelings among the peoples". ${ }^{135}$ While this shows that Turkish authorities wish Turkey to be perceived as a saviour, and not an oppressor, 'the small group of authors and historians' as described by Bayraktar has a considerable influence. In reality Bayraktar's simplistic version obscures a bigger challenge as shown by recent requests by Turkish authorities that the Albanian and Kosovar governments alter Albanian schoolbooks, and portray Ottomans as "friendly administrators" ${ }^{36}$, or better yet, 'protectors' who brought about political stability to the Albanian speaking lands. This is a complex issue, which continues to cause trouble in the relations between Turkey and Albania. Furthermore, the antiOttoman camp, which was 'funded' by the Albanian rilindja writers, is now led by the prominent Albanian writer - Ismail Kadare, who has written extensively about his concern that Albania is growing too close to Turkey again. ${ }^{137}$

\section{Geopolitics and energy security drivers in the Albanian-Turkish relations}

In the twenty-first century, Albania is hoping to strengthen its geopolitical position in the region with two main projects: The Trans Adriatic Pipeline (TAP) and the PanEuropean Corridor VIII. Turkey also has a direct interest and involvement in both projects.

In February 2013, after ten years of negotiation and assessments ${ }^{138}$, TAP was selected as the best project to bring Caspian natural gas from the Shah Deniz gas field to Italy

\footnotetext{
${ }^{132}$ In 1997, the bankruptcy of 25 Albanian firms, or known as the pyramidal scheme, plunged the country in a total economic and political turmoil. The Albanian government lost partial control of its territory to armed gangs.

${ }^{133}$ It seemed that Albania's historical neighbours, Serbia and Greece had their own agendas in 1997, a time when the Albanian state lost control of the Albanian territory, after the quasi civil war. The "ghost" of Vorio-Epirus was resurrected when the Greek flag was flown in protests in Saranda, Delvinë and Gjirokastër in south Albania; whereas the north and the rest of the counter was under the Serbian rule. See H. Limaj, Midis Ankarasë dhe Tiranës: 1990-2000. Nga ditari i një atasheu ushtarak [Between Ankara and Tirana: 1990-2000. From the diary of a military attaché], pp. 106-108.

${ }^{134}$ H. Limaj, pp. 108-109.

${ }_{135}$ G. Mlloja, "Relations between Turkey and Albania are at an excellent level”.

${ }^{136}$ A. Rrozhani, "Qeveria e Shqiperise ka firmosur per ndryshimin e historise : Osmanet jo pushtues por 'administratore miqesore' [ Albanian government signed for changing the history: Ottomans not as invaders, but "friendly administrators']", 26 August 2011, retrieved from 24 Ore, available from http://24ore.com/index.php/kronika/7464-qeveria-e-shqiperise-ka-firmosur-per-ndryshimin-e-historise-osmanet-jopushtues-por-administratore-miqesore.html, last viewed on 6 October 2011.

${ }^{137}$ For Kadare from "the clash of two civilisations", Oriental-Ottoman Empire and Occidental-Europe, the "balkan peninsula" (considered "the cradle of [Europe's] civilization"), was removed from the body of the old "mother", Europe. Kadare's main concern is that such things may happen again. Therefore he is building his thesis on the idea that Albania will definitely abandon the Turkish 'route' and focus on the Euro-Atlantic path in the future. See for instance I. Kadare, Identiteti evropian i shqiptarëve [The European identity of the Albanians], Onufri, Tirana, 2006, p. 59.

138 “TAP project millestones": Trans Adriatic Pipeline.
} 
and largely, Europe. The pipeline will be connected to the Turkish Trans Anatolian Pipeline (TANAP) at the Greek-Turkish border. TANAP will then connect to the South Caucasus Pipeline Expansion (SCPX) that runs across Georgia and Azerbaijan. TAP will be $870 \mathrm{~km}$ long and will cross Greece, Albania and the Adriatic Sea to deliver the gas to Santa Foca (Lecce, Italy).

The aim of TAP is to diversify Europe's energy sources, which at the moment are heavily dependent on Russia. TAP's significance was amplified after Russia annexed Crimea on 18 March 2014. After this event, the conflict of some EU countries and Russia deepened, and consequently, American and European sanctions were placed on Russia. All countries involved in this project: Azerbaijan, Georgia, Italy, Turkey, Greece and Albania hope to advance their relations with the EU, as TAP will place them in a favourable position compared to other regional neighbours. It remains to be seen whether bilateral relations between the not-yet EU members - Turkey and Albania, may become fruitful as a result of energy and security matters.

Nevertheless, TAP offers an economic win-win situation for all countries the gas pipeline runs through. Turkey, Greece and Albania - all NATO members, are countries that will generate income for their economies. For Albania, TAP is currently the biggest international investment ${ }^{139}$, placing Albania, Turkey and Greece at the centre of energy security policies within the EU. TAP may also restore new trilateral relations between Turkey, Greece and Albania after centuries of extremely troubled relations. ${ }^{140}$ Nevertheless, the latest shifts of Turkey's foreign policy designed to develop a closer relationship with Moscow ${ }^{141}$, allow Russia to deliver its gas to Turkey through the 'Turkish Stream' pipeline situated only $10 \mathrm{~km}$ from TAP. ${ }^{142}$

\section{The new landscape in South Eastern Europe: Pan-European Corridor VIII}

In looking at the European energy and infrastructure distribution map, it is obvious that the western Balkans area has been left behind. Although three Pan-European conferences in Prague (1991), Crete (1994) and Helsinki (1997) established ten panEuropean corridors within Central, Eastern and South-eastern Europe, for a long time, due to economic restraint and lack of local resources, one of the greatest projects - the PAN European Corridor VIII, has not been considered as one of "the Top 30" priority projects by European Union. ${ }^{143}$ However, the latest developments require a reassessment of the Corridor VIII, which include energy and infrastructure axis in the Western Balkans and South East Europe. There are several reasons for this: the completion of the Napoli-Bari high capacity railway, which will connect the port of Bari to Corridor I (Palermo-Berlin); the need to connect with Corridor X and VI, which will facilitate a better and fast connection with new prospective EU countries such as

\footnotetext{
139 "Building the pipeline in Albania": Trans Adriatic Pipeline.

${ }^{140}$ O. Demetriou, Capricious Borders: Minority, Population, and Counter-Conduct Between Greece and Turkey, Berghahnbooks, United States, 2013, p. 2.

${ }^{141}$ Putin recently rectified the agreement to deliver gas through Turkish stream. See "Putin dhe Erdogan armiq të betuar? Marrëveshja e madhe e bashkëpunimit [Putin and Erdogan sworn enemies? The big friendship agreement]".

${ }_{142}$ D. Munteanu and C Sarno, "Nord Stream 2 and Russia-Turkey Pipeline: Implications for European Energy Security", University of Bologna, March 2016, p. 10.

${ }_{143}$ A. Nikodinovska, "Renewal of the Albano-Macedonian and Turkish relations: the perspectives of the Corridor VIII”, in M Bulut and M Idriz (eds.), Turkish Albanian Macedonian Relations: Past, Present and Future: AdamActor, Ankara, 2012, p. 264.
} 
Turkey and Serbia; a better connection with Bulgaria - an EU country that can act as 'a strategic node' in the new landscape of the South East Europe. More importantly, Corridor VIII will "connect the countries of the European Union with the Caspian basin". ${ }^{144}$

The Corridor VIII axis will have "a total length of $1270 \mathrm{~km}$ in rail tracks and $960 \mathrm{~km}$ of roads", but also "consists [of] sea and river ports, airports, multimodal ports, roads and railways". ${ }^{145}$ In Albania this Corridor is known as Via Egnatia, and has existed since the second century BC. WWI ended its use. However, Via Egnatia has remained a cultural and archaeological site of what was once considered as "the biggest nexus between East and West". ${ }^{146}$ The Romans linked Via Apia (Italy) with Via Egnatia, which facilitated the flow of goods and people from Rome to Constantinople and thus, between the Roman and Byzantine Empires. Via Egnatia was not merely a simple transport facility: for both East and West, it "meant connectivity, trade, travel, purpose, prosperity". ${ }^{147}$ The historical importance of Via Egnatia is enormous, and its reconstruction will bring Turkey physically closer to the Balkans; a connection that currently exists through historical ties and the Ottoman legacy. ${ }^{148}$

The Pan-European Corridor VIII in Albania is certainly a revival of Via Egnatia, which connected Durrës with Tirana and Elbasan and ran along the Shkumbin River to connect Bitola, Skopje, Kumanovo, Sofia, Dimitrovgrad, Burgas; ending at the Black Sea at the port of Varna. For Albania, this Corridor is crucial as it not only connects the East with the West, but it also acts as a catalyst for "the relationship between Turkey, Macedonia and Albania". ${ }^{149}$ Although the Corridor VIII still remains imaginary due to obstacles created by "the lack of a railway connection between Bulgaria and Macedonia", Bulgaria is joining forces with Italy to make the Corridor VIII an "EU priority". ${ }^{150}$

Corridor VIII and TAP will change the geopolitical landscape of the Western Balkans and South Eastern Europe. As a result, both projects, TAP and the Corridor VIII, may further prioritise relations with Albania in the eyes of Istanbul. As a result of interests and the geographical position of Turkey, these projects may generate a new dimension of Turkey's relations with Muslim populations in the Western Balkans. It is not hard to predict that Albania is vulnerable to Turkey's foreign policy shifts. Therefore, both projects, TAP and Corridor VIII, are likely to be triggers for Turkey and Albania to strengthen their bilateral relations, as they may need each other. The Ottoman narrative may be still present, however, in a globalised world, economic and political interests might be able to supersede this narrative.

\section{Conclusion}

This paper analysed increasing bilateral relations between Turkey and Albania with regards to economy, foreign policy, energy and security matters since the creation of

\footnotetext{
${ }^{144}$ A. Nikodinovska, p. 263.

${ }^{145}$ A. Nikodinovska, p. 262.

${ }^{146}$ M. Bulut and M. Idriz, Turkish Albanian Macedonian Relations: Past, Present and Future, p. 9.

${ }_{147}$ A. Nikodinovska, "Renewal of the Albano-Macedonian and Turkish relations: the perspectives of the Corridor VIII", p. 260.

${ }^{148}$ M. Todorova, Imagining the Balkans, Oxford University Press, New York, 2009, p. 199.

${ }^{149}$ A. Nikodinovska, "Renewal of the Albano-Macedonian and Turkish relations: the perspectives of the Corridor VIII", p. 261.

150 "Bulgaria, Italy Join Forces to Make Corridor 8 EU Priority": Sofia News agency: Novinite, 31 March 2012.
} 
both nation-states. Until the end of the Cold War, diplomatic relations between Turkey and Albania were intermittent, but friendly, and did not affect the excellent relations between the two countries. A poor Albania at the end of the Cold War provided a "golden" opportunity for Turkey to get closer. Albania on the other hand, needs Turkey's economic and military power in the region. In the twenty-first century, political relations between Albania and Turkey have reached a new importance.

Although Turkey is Albania's strategic partner, trade between the two countries has not yet reached its full potential. Things are different when it comes to defence and security matters. The Albanian government favours Turkey compared to other neighbours in the Western Balkans. The excellent political relations between the two countries will improve even further after the energy and infrastructure projects such as TAP and the Corridor VIII have been implemented. It remains to be seen how these developments will affect the Euro-Atlantic vision of both countries.

Turkey has indeed helped the weaker Albania during those times that Albania desperately needed Turkish support. While the Turkish economic, political and military support is done in a 'soft power' fashion in order to accommodate Albanian needs, Turkey stepped forward in 1999 participating in NATO's war against Milosevic. The question to be asked is whether the intensity of Turkish support will create conditions for a future Albanian shift towards Turkey, at a time when Europe's internal unity is challenged by Brexit, Russia's occupation of the Ukraine, refugees from Syria and Iraq, whilst the EU is anxiously awaiting agreements between the two powerful presidents, Vladimir Putin and Donald Trump. The new dynamics of interactions between the two powerful presidents can shift the political and military balance of power and territorial contests in the Balkans. Kosovo's fate may depend on new agreements reached by Putin and Trump, while at present, Serbia is getting new armaments from Russia ${ }^{151}$, whereas Serbian media is claiming that Kosovo is receiving armaments and training from Turkey. ${ }^{152}$ The day of a permanent peace in the Balkans seems to have not yet arrived. Until then, there is no doubt that relations between Albania and Turkey will only strengthen.

\footnotetext{
${ }^{151}$ On 5 February, the Serbian defence minister declared that Serbia ordered 30 tanks, and as many armored vehicles from Russia, six MIG 29s fire jets and was still negotiating for another eight. "Serbia set to get Russian fighter jets", Boston Globe.

${ }^{152}$ Serbian media points out Erdoğan's intention to provide Kosovo free armoured vehicles, tanks, F-16 Falcon fire jets, and also training how to use them. "Goditje tjetër e medieve serbe: Turqia armatos shqiptarët për luftë, Erdogan i jep Thaçit aeroplanë! [Another blow from the Serbian media: Turkey is arming Albanians for war, Erdogan gives Thaçi military airplanes!”, Telegrafi.com.
} 